\title{
ALLAH MEMANGGIL UMAT-NYA UNTUK MENJADI GEREJA YANG TEKUN BERDOA MENURUT KISAH \\ PARA RASUL 4: 23 - 31 \\ Daniel Sutoyo ${ }^{1}$
}

\begin{abstract}
Abstraksi
Doa merupakan sebuah aktivitas yang erat hubungannya dengan denyut nadi kekristenan; sehingga muncul semacam ungkapan, bahwa doa adalah nafas kehidupan orang percaya. Sejatinya, kegiatan doa bukanlah sebuah rutinitas ibadah belaka, melainkan pusat kehidupan itu sendiri. Dari zaman Yesus ada di muka bumi hingga pada pelayanan para rasul di Yerusalem bersama jemaat mulamula, doa menjadi energi dari setiap pelayanan bahkan sendi kehidupan yang dilakukan. Artikel ini menyajikan sebuah telaah eksegetis tentang doa dalam Kisah Para Rasul 4:23-31, yang bertujuan menunjukkan secara biblikal sifat doa yang penting dan urgen. Pada akhirnya, gereja didorong untuk memahami esensi doa dan mulai berdoa dengan tekun.
\end{abstract}

Kata kunci: doa, berdoa, gereja, Kisah Para Rasul, rasul

God's Calling on His Church for Pray According to Acts 4:23-31

\begin{abstract}
Pray is an activity most related to Christian's life; so there is a saying that prayer is believers' breath of life. Substantially, praying is not mere routinized of service, but also life center. From the time of Jesus was on earth untill the apostles' ministry with early church in Jerusalem, pray becomes energy of every ministry even life. This article is giving an exegetical study of pray in Acts 4:2331 , which aim to show biblically character of pray, which is important and urgent. At least, it encourages church to understand the essence of pray and begin to pray on and on.
\end{abstract}

Keyword: prayer, pray, church, Acts, apostle

${ }^{1}$ STTIntheos Surakarta (danielsutoyo@gmail.com) 


\section{PENDAHULUAN}

Pasca modernisasi sekarang ini membuat manusia dapat melakukan segala sesuatu dengan cepat, praktis dan simple apapun yang diinginkan. Demikian juga orang percaya pada saat ini, membuat waktu mereka tersita untuk kegiatan dan pekerjaan yang mereka lakukan, sehingga tidak lagi bergairah untuk bersekutu dan berdoa. Beberapa orang Kristen lebih banyak menghabiskan waktu untuk bekerja, melakukan ini dan itu, sehingga tidak ada waktu lagi untuk melakukan persekutuan maupun doa pribadi. Terkadang mereka berdoa hanya sebagai rutinitas sebagai orang Kristen saja, mereka tidak menyadari akan penting berdoa sebagai wujud persekutuan dengan Tuhannya. Bagaimana dengan gereja mula-mula yang sangat antusias untuk bersekutu dan berdoa? Masih relevankah gaya hidup gereja mula-mula untuk semangat berdoa untuk masa kini?

Saya pernah membaca buku yang berjudul Menjalankan Misi Bersama Yesus karya Andrew Brake $^{2}$ yang mengilustrasikan berdoa itu seperti membuat kue tart ulang

\footnotetext{
${ }^{2}$ Andrew Brake, Menjalankan Misi Bersama Yesus (Bandung: Kalam Hidup, 2016), 87-94.
}

tahun. Membuat kue tart ulang tahun membutuhkan tepung,gula, pengembang, telur, garam dan bahanbahan penyedap lainnya agar kue tart itu menjadi lezat. Bayangkan jika kue tart tanpa garam, kue itu tidak enak atau kue itu menjadi pahit. Bagaimana kue tart tanpa pengembang? Kuenya tidak akan mekar, ya mungkin berisi, namun kuenya menjadi keras, tidak lembut, tidak menarik. Atau kue itu tanpa garam, kue itu hambar, tidak lezat. Apa hubungannya antara doa dengan bahan-bahan untuk membuat kue tart? Bahan kue tart, antara lain; tepung adalah bahan utama kue, merupakan gambaran dasar doa yaitu mengakui kekuasaan dan kedaulatan Allah. Bahan gula; mengakui bahwa dalam doa Allah mempunyai rencana itulah manisnya doa. Bahan pengembang kue merupakan gambaran dalam berdoa supaya diberikan keberanian untuk bangkit menghadapi masalah. Dan bahan garam merupakan dampak dari doa itu.

Dalam Alkitab banyak contoh, tips, cara bagaimana berdoa, seperti ada doa Bapa Kami, Yesus berdoa semalam-malaman, Elia berdoa, Hana 
berdoa, ada juga mazmur doa, dan pribadi-pribadi yang berdoa,dan lainlain. Dalam Kisah Para Rasul 4: 23 31 ini, hanya salah satu contoh doa yang penuh kuasa, supaya orangorang Kristen bertekun berdoa,sehingga mereka menjadi pribadi-pribadi yang berdampak sebagai orang yang percaya, bagi gereja, bagi masyarakat dan bagi Negara Indonesia.

\section{TEKUN BERDOA}

(Refleksi Kisah Para Rasul 4:23-31)

\section{Latar belakang Kisah Para Rasul}

Kisah Para Rasul bukan saja buku sejarah dari gereja mula-mula, tetapi dapat dijadikan buku pedoman bagi kehidupan Kristen dan untuk gereja yang dipenuhi Roh Kudus. Orang percaya seharusnya mendambakan buku Kisah Para Rasul, sebagai norma atau patokan gereja masa kini, dalam kaitannya pelayanan dan pengalaman hidup serta perkembangan gereja dalam Perjanjian Baru. Kitab Kisah Para Rasul mencatat apa yang seharusnya gereja perbuat di dalam setiap generasi selama ia melanjutkan pelayanan Yesus dalam kuasa Pentakosta dari Roh Kudus.
Ferdinand Christian Baur, dari sudut pandang sepihak, berpendapat bahwa jemaat yang digambarkan dalam Kisah bukanlah laporan historis, melainkan merupakan hasil refleksi teologis. ${ }^{3}$ Baur, sebagai teolog Tubingen abad XIX yang terkemuka, berpendapat bahwa maksud teologis penulis Kisah Para Rasul adalah mempersatukan para rasul dengan jemaat perdana ke dalam satu persekutuan orang-orang kudus. Menurut Baur, sejarah yang tercermin dalam Kisah Para Rasul dan dalam diri Paulus sendiri sama sekali berbeda. Pada awal abad XX, pendapat Baur ini dikembangkan oleh Heinrich Julius Holtzmann, ${ }^{4}$ dan sekalipun ditentang oleh beberapa ahli, termasuk Adolph Schlatter. ${ }^{5}$

Dalam kurun setengah abad terakhir, masalah ini masih menjadi perdebatan hangat. Bultmann dan para pengikutnya mengembangkan

\footnotetext{
${ }^{3}$ Hal ini dapat dilacak dalam W. W. Gasque, $\boldsymbol{A}$ History of the Criticism of the Acts of the Apostles (Grand Rapids: William B. Eerdmans, 1975) dan Werner Georg Kümmel, The New Testament: The History of the Investigation of Its Problems (London: SCM, 1973); W.G. Kümmel, Introduction to the New Testament (London: SCM, 1975), 125-88.

${ }^{4}$ Heinrich Julius Holtzmann, "Lehrbuch der neutestamentlichen Theologie" (Tubingen: Mohr, 1911).

${ }^{5}$ Adolph Schlatter, "Neutestamentliche Theologie" (Stuttgart: Calwer, 1922-1923).
} 
tesis Baur dan berpendapat bahwa kristologi Kisah Para Rasul mencerminkan teologi pra-Paulus, sedangkan teologi naturalisnya, eskhatologinya serta pandangannya atas Taurat mencerminkan gagasangagasan post-Paulus. Jadi, teologi Kisah Para Rasul tidak mencerminkan keadaan jemaat perdana, melainkan katolikisme awal yang sedang bertumbuh. $^{6}$ Ernst Kasemann menandaskan bahwa penulis Kisah melegitimasi pandangannya tentang jemaat dalam hubungannya dengan pandangan bidat, berdasar kontinuitasnya dengan kerasulan awal dan kesuciannya di dunia ini. Kasemann berpendapat bahwa penulis Kisah adalah pelopor katolikisme awal. $^{7}$

Holger Conzelmann, dengan karyanya The Theology of St. Luke (1960), memodifikasi penelitian Holtzmann, Klein, Bultmann, dan Kasemann, dan berpendapat bahwa penulis Kisah Para Rasul menggambarkan keadaan jemaat mula-mula. Berdasar pendekatan

${ }^{6}$ Lht. James D.G. Dunn, Unity and Diversity in the New

Testament(Philadelphia: Westminster, 1977), 341-67.

${ }^{7}$ Ernst Kasemann, Essays on New Testament Themes (London: SCM, 1960), 88-94. sejarah keselamatan, Conzelmann memberi garis besar alasannya: 1) pusat pewartaan Kisah Para Rasul adalah zaman Yesus, bukan zaman gereja; 2) teologi Kisah Para Rasul seharusnya tidak dibandingkan dengan teologi Paulus, karena masalah yang dihadapi Kisah Para Rasul bukanlah masalah yang dihadapi Paulus, seperti masalah tertundanya parousia dan keberadaan gereja dalam sejarah sekular; 3) ciri khas komposisi historis yang digunakan penulis Kisah Para Rasul untuk memecahkan masalah adalah pembagian sejarah keselamatan dalam tiga episode: (a) zaman Israel (zaman PL); (b) sentral sejarah keselamatan, yaitu zaman Yesus; dan (c) zaman gereja, yang merupakan zaman perjuangan antara kebimbangan dan kesabaran; 4) dengan periodisasi ini, penulis bermaksud menjelaskan kepada jemaat pada zamannya, bahwa bentuk gereja boleh saja berubah, sekalipun struktur fundamentalnya harus tetap dipertahankan. ${ }^{8}$

Dengan alasan di atas, Conzelmann menolak akurasi historis Kisah Para Rasul dan menganggap

${ }^{8}$ Holger Conzelmann, The Theology of St. Luke (London: Faber, 1960), 14-17. 
pemikiran penulis Kisah Para Rasul sebagai penyimpangan pemikiran

Paulus dan Yohanes. Cullmann menyanggah konsepsi Conzelmann ini. ${ }^{9}$ I. Howard Marshall, mengembangkan karya W.M. Ramsay ${ }^{10}$ dan A.N. Sherwin-White, ${ }^{11}$ berpendapat bahwa penulis Kisah Para Rasul adalah seorang sejarawan dan teolog. ${ }^{12}$ Karena itu, tidak mengherankan jika banyak kritikus meyakini bahwa penulis Kisah Para Rasul telah menyajikan gambaran mengenai kehidupan dan pemikiran jemaat perdana yang dapat dipercaya. Dengan demikian, Kisah Para Rasul dapat dianggap sebagai sumber teologi jemaat perdana yang dapat dipercaya.

Tanpa mengabaikan pertimbangan historis, penelitian mutakhir berusaha memahami teologi

\footnotetext{
${ }^{9}$ Oscar Cullmann, Salvation in History (London: SCM, 1967).

${ }^{10}$ William Mitchell Ramsay, berdasar studi geografis dan arkheologis, berpendapat bahwa sejarah Lukas luar biasa akurat. Lih. W.M. Ramsay, The Bearing of Recent Discovery on the Trustworthiness of the New Testament (London: Hodder \& Stoughton, 1915).

${ }^{11}$ Adrian Nicholas Sherwin-White, seorang sarjana klasik, berkesimpulan bahwa konfirmasi historis Kisah sangat berlimpah. Lih. Sherwin-White, Roman Society and Roman Lawin the New Testament (London: Oxford, 1963), 189-200.

${ }^{12}$ I. Howard Marshall, Luke: Historian and Theologian (Grand Rapids, Michigan: Zondervan, 1970).
}

Kisah Para Rasul berdasar tempatnya dalam kanon. ${ }^{13}$ Menurut Parsons, berdasar posisi kanoniknya, gambaran Kisah Para Rasul mengenai kehidupan jemaat perdana dapat diterima sebagai sejarah yang memadai. $^{14}$ Apa pun manfaat pendekatan ini bagi penelitian historis, tidak dapat disangkal bahwa bagaimanapun karya penulis Kisah Para Rasul ini merupakan karya teologis, sebagaimana dikatakan J. C. Beker, "Lukas adalah seorang teolog besar."15 Memang, penulis Kisah Para Rasul tidak menyatakan bahwa ia menulis suatu karya teologis, namun tulisannya merupakan informasi teologis dan secara signifikan

\footnotetext{
${ }^{13}$ Lih. Mikeal Parsons, "Canonical Criticism," dalam David Alan Black dan David S. Dockery (eds.), New Testament Criticism and Interpretation (Grand Rapids: Zondervan, 1991). Hermeneutika kanonik tidak menolak masalah historisitas Kisah, tetapi menempatkan persoalan ini dalam hubungannya dengan masalah lain; lihat juga Parsons, "The Sense of a Beginning in Acts 1-5," dalam Rev Exp 87 (Summer, 1990), 403-422.

${ }^{14}$ Lih. George Eldon Ladd, $\boldsymbol{A}$ Theology of the New Testament (Grand Rapids: Eerdmans, 1974), 314; bdk. Donald Guthrie, New Testament Theology (Downers Grove, IL: InterVarsity, 1981), hlm. 42-48; lihat juga Douglas Dockery, "Acts 6-12: The Advancement of the Christian Mission Beyond Jerusalem," RevExp 87 (Summer, 1990), 423-38; John Polhill, "Acts 6-12: The Hellenist Breakthrough," RevExp 71 (1974), 475-486.

${ }^{15}$ J. C. Beker, Paul the Apostle

(Philadelphia: Fortress, 1980), 162.
} 
memberi andil terhadap pemahaman kita atas teologi Perjanjian Baru. ${ }^{16}$

Lukas sebagai penulis Kisah Para Rasul adalah seorang yang sangat peduli dengan perilaku doa. Lukas mencatat tentang doa biasanya dikaitkan dengan peristiwa-peristiwa penting dalam kehidupan Yesus dan umat-Nya. Doa yang diatkan dengan baptisan (Luk. 21); setelah hari-hari Yesus mengadakan mujizat (Luk. 5:15-16); sebelum memilih para murid (Luk.6: 12); sebelum pemberitahuan pertama akan penderitaan Tuhan Yesus (Luk. 9: 1822); pemuliaan (Luk. 9: 29); kembalinya ketujuh puluh murid (Luk. 10: 17-21); sebelum mengajar bagaimana para murid berdoa (Luk.11:1); di Getsemani (Luk. 22: 39-46); dan di atas kayu salib (Luk. 23: 24). Ia pernah mengundurkan diri dari padang gurun (Luk. 5: 16); Ia berdoa sepanjang malam (Luk. 6: 12). Ada perumpamaan tentang berdoa, yaitu teman di tengah malam (Luk. 11: 5, dst) dan janda yang gigih memohn kepada hakim (Luk. 18: 18). Hanya Lukas yang mencatat Yesus berdoa bagi Petrus (Luk. 22:

\footnotetext{
${ }^{16}$ Leon Morris, New Testament

Theology(Malang: Gandum Mas, 1999), 144145.
}

31-32); mendorong para murid untuk berdoa di Getsemani (Luk. 22: 40); berdoa bagi para murid (Luk. 23: 34) dan bagi diri-Nya (Luk. 22: 41). Lukas juga menyatakan bahwa Yesus berdoa di tempat yang sunyi (Luk. 4: 42); menyingkir ke Betsaida (Luk. 9: 10); Ia keluar malam-malam untuk pergi ke Bukit Zaitun (Luk. 37).

Demikian juga dalam Kitab Kisah Para Rasul, Lukas mencatat banyak tentang umat-Nya yang berdoa. Murid-murid-Nya dengan para perempuan bertekun berdoa menantikan pencurahan Roh Kudus (Kis. 1: 12-14): murid-murid berdoa untuk meminta kehendak Tuhan untuk mengganti Yudas (Kis. 1: 2326); Murid-murid mempunyai gaya hidup salah satu bertekun dalam doa (Kis. 2: 42); Petrus dan Yohanes biasa berdoa di Bait Allah (Kis. 3: 13); para rasul berdoa untuk untuk Petrus dan Yohanes yang dipenjarakan oleh Sanhedrin (Kis. 4: 23-31); para rasul berdoa untuk menahbiskan para diaken yang terpilih (Kis. 6: 3-6); Petrus dan Yohanes berdoa untuk baptisan Roh Kudus bagi orang-orang Samaria (Kis. 8: 14-17); umat-Nya berdoa untuk pembebasan Petrus dari penjara 
(Kis. 12: 5, 12-17); Gereja Antiokhia berdoa dan berpuasa bagi para rasul untuk menjadi misionaris (Kis. 13: 13); Jemaat dan rasul-rasul berdoa dan berpuasa untukmenetapkan para penatua (Kis. 14: 23); Paulus setiap pergi mencari rumah sembahyang untuk berdoa (Kis. 16:13, 16); Paulus dan Silas berdoa di tengah malam di dalam penjara Filipi (Kis. 16: 25-26); Paulus berdoa dengan para penatua gereja Efesus (Kis. 20: 36-38); dan Murid-murid sedang berdoa mendapat bisikan Roh Kudus yang melarang Paulus pergi ke Yerusalem (Kis.21: 4-6) .

\section{Konteks Kisah Para Rasul 4: 23-31}

Kisah Para Rasul 4: 23-31 adalah bagian akhir dari episode panjang yang dimulai dari Kisah Para Rasul 3: $1 .^{17}$ Orang-orang yang mengadukan Petrus dan Yohanes karena mujizat penyembuhan berakibat mereka masuk dalam penjara. Para rasul yang selanjutnya menghadapi Sanhedrin, yang mengancam mereka, karena keberanian mereka memberitakan Yesus yang bangkit dengan menyatakan penyembuhan. Bagian

\footnotetext{
${ }^{17}$ C. K. Barrett, Concurs in The Acts of the Apostles (Edinburgh: T \& T Clark, 1994), 241.
}

ini mencatat kesimpulan doa untuk rangkaian peristiwa-peristiwa yang ajaib. Ini jelas dimulai dalam ayat 23 karena Petrus dan Yohanes secara special dilepaskan dari penjara kemudian mereka mendatangi temantemannya.

Dan bagian ini diikuti dengan ringkasan aktivitas komunal orangorang percaya dan pertumbuhan dan perkembangan gereja (4:32 -35). Keistimewaan kitab Kisah Para Rasul yang dilengkapi ringkasan secara teratur dan sebagai tanda istirahat dari episode yang satu dengan episode lainnya (lih. 2:42-47; 6:7; 9:31; 12:24). Oleh karena itu, ayat 31 cukup pasti sebagai bentuk akhir dari bagian ini.

Penuh dengan Roh Kudus dan berani memberitakan Injil sebagai hasil doa dalam Kisah Para Rasul 4: 23-31. Pola ini sama dengan yang dapat kita temui pada awal hari Pentakosta,di mana para rasul yang berdoa, menantikan kuasa Roh yang memberdayakan umat-Nya untuk meberitakan Injil (Kis. 2:1-41). Oleh karena kuasa Roh Kudus yang telah membaptis dan memenuhi para rasul adalah kuasa (dynamis) untuk menyembuhkan, menyatakan tanda- 
tanda dan mujizat-mujizat akhirnya pada gilirannya para rasul dapat kesempatan untuk menyampaikan kerygmatik rasuli ${ }^{18}$

Kisah Para Rasul 4: 23-31 menguraikan tentang doa di dalam jemaat gereja mula-mula, secara struktur yang logis dapat dipaparkan sebagai berikut;

1. Ayat 23-24 merupakan pernyataan kedaulatan Allah bagi doa orang-orang percaya kepadaNya.

2. Ayat $25-28$ Allah mempunyai rencana bagi doa orang-orang percaya.

3. Ayat 29-30 menyatakan isi doa supaya berani memberitakan Injil.

\footnotetext{
${ }^{18}$ Yang dimaksud dengan kerygmatik rasuli adalah khotbah-khotbah atau pidatopidato para rasul pada gereja mula-mula yang mencakup banyak hal, atau inti dan pokok pemberitaan para rasul gereja mula-mula. Kerygmatik rasuli pada umumnya dengan sistematika, sebagai berikut: 1) Pelayanan mujizat-mujizat Yesus, penederitaan Yesus, kematian Yesus dan Kebangkitan Yesus, karena Allah membuat Yesus bangkit dari kematian. 2) Pemuliaan Yesus: Tuhan Yesus dimuliakan, membangkitkan dia pada tangan kanan-Nya sebagai Mesias, Raja, Juruselamat dan Tuhan. 3) Semua yang terjadi telah dinubuatkan oleh kitab-kitab Perjanjian Lama, Yesus menggenapi janji Perjanjian Lama. 4) Keselamatan: kebangkitan Yesus yang mendatangkan keselamatan setap orang percaya kepada-Nya, maka para rasul mendesak orang-orang untuk bertobat dan menerima Roh Kudus, hanya di dalam Yesus dijanjikan pengampunan, kasih karunia, keselamatan, hidup baru dalam nama-Nya.
}

4. Ayat 31 merupakan pernyataan dampak doa yang penuh kuasa.

\section{Hakekat Doa}

\section{Fondasi Doa: Kedaulatan Allah}

Doa umat Allah pada gereja mula-mula dimulai dengan kutipan dari Keluaran 20:11. ${ }^{19}$ Konteks dari kutipan tersebut adalah upacara perjanjian antara bangsa Israel dan Tuhan di Gunung Sinai mengenai pembebasan umat-Nya dari perbudakan di Mesir. Dalam Kisah Para Rasul 4: 23-31 mengandung salah satu doa yang menginspiratif dalam Alkitab, karena pada saat itu orang-orang percaya dalam keadaan berbahaya. Dalam aktifitas doa ini, Petrus dan Yohanes ditangkap setelah penyembuhan seorang lumpuh. Para rasul pasti tahu itu bukan ancaman belaka, akan tetapi dengan mujizat kesembuhan itu, para rasuldengan berani memberitakan Injil. Para rasul sudah mengalami pencurahan Roh Kudus pada hari Pentakosta dan menyadari kebutuhan mereka untuk kekuasaan ilahi. Sebab mujizat penyembuhan yang terjadi merupakan

\footnotetext{
${ }^{19}$ F. F. Bruce, The Acts of the Apostles: The Greek Text with Introduction and Commentary (Chicago: Inter-Varsity Christian Fellowship, 1952), 126
} 
kedaulatan

Allah. Brake

menghancurkan. $^{21}$ Di sini kata ini menggambarkan bahwa pondasi doa dalam Kisah Para Rasul ini digambarkan denga bahan kue tart yang pokok yaitu tepung. ${ }^{20}$ Kedaulatan Allah harus menjadi pondasi dan substansi doa umat-Nya.

Ketika teman-teman Petrus dan Yohanes mendengar bahwa mereka menghadapi kesulitan dalam pelayanannya, maka umat-Nya bersama-sama berseru kepada Allah, katanya: "Ya Tuhan, Engkaulah yang menjadikan langit dan bumi, laut dan segala isinya..." (Kis.4: 24).Pernyataan "berserulah mereka bersama-sama kepada Allah,

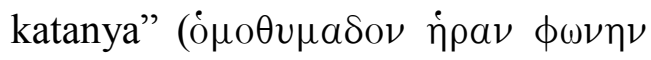

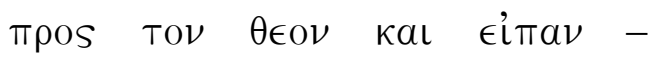
homothumadon heran phōnen pros ton theon kai eipan) secara literal berarti dengan sehati mereka mengangkat suara kepada Allah dan

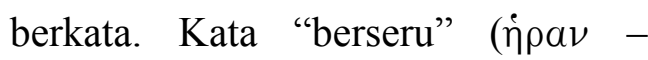
hêran) aorist active indicative dari kata aipw (airō) yang berarti mengangkat, membawa (serta), memindahkan, mengambil, menyingkirkan (dengan kekerasan, bahkan dengan membunuh,

\footnotetext{
${ }^{20}$ Brake, Op.cit., 88.
} berarti mengangkat suara dengan segenap dan sepenuh hati. Artinya doa yang dipanjatkan bersama-sama kepada Allah merupakan doa yang mempunyai kesatuan hati dan pikiran. Sebab Tuhan senang mendengar dan menjawab doa yang disampaikan dengan kesatuan hati, bukan perpecahan dalam gereja. Jadi setelah komunitas Kristen itu mendengar cerita apa yang dialami oleh kedua rasul ketika di hadapan Mahkamah Agama bangsa Yahudi, maka mereka berserulah atau mengangkat suara (bdk. Kis.1:14; 2:46; 5:12; 7:57; $15: 25)$.

Mereka berdoa dengan mengatakan "Ya Tuhan, Engkaulah yang menjadikan langit dan bumi, laut dan segala isinya." Ungkapan "Ya Tuhan" ( $\Delta \in \sigma \pi$ Tота - despota) yang berasal dari kata $\delta \in \sigma \pi O T \eta S$ (despotēs) yang berarti tuan, Penguasa, Tuhan. ${ }^{22}$ Kata Yunani yang biasa untuk Tuhan adalah kurios, tetapi kata ini kurang umum digunakan dalam ayat 24 ini. Kata despotēs, yang berarti tuan, penguasa atau Tuhan sering menunjukkan "sebuah despotik, yaitu jenis

\footnotetext{
${ }^{21}$ Susanto, Op.cit., II: 29.

${ }^{22}$ Ibid., 190
} 
kewenangan Tuhan sebagai Penguasa langit dan bumi. Namun, di sini itu tepat digunakan untuk mengungkapkan kontrol yang kuat yang diberikan oleh Allah kepada umat-Nya. ${ }^{23}$ Biasanya kata ini menunjukkan hubungan antara majikan dan budak atau pembantu, yang mana majikan berkuasa penuh terhadap hamba-hambanya (1Tim. 6: 1; 2Tim. 2:21; Tit. 2: 9; 1Ptr. 2:18). Lukas hanya menggunakan di sini dan Lukas 2: 29 tentang doa Simeon, "Sekarang, Tuhan, biarkanlah hamba$\mathrm{Mu}$ ini pergi dalam damai sejahtera, sesuai dengan firman-Mu." Kata ini diterjemahkan dengan "Penguasa" (2Ptr. 2: 1; Yud. 1: 4; Why. 6:10). Kata ini berbeda dengan kata yang biasanya (kurios), meskipun artinya tidaklah berbeda, hanya kata despotēs dapat juga berarti penguasa, pemilik, pengatur.

Sedangkan ungkapan "Engkaulah yang menjadikan langit dan bumi, laut dan segala isinya" ( $\sigma v$

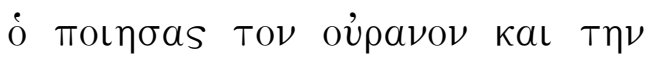

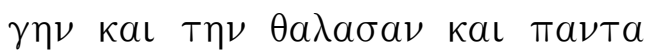
Ta $\epsilon \hat{v}$ aủTols - su ho poiēsas ton ouranon kai tēn gēn kai tēn thalasan

\footnotetext{
${ }^{23}$ I. Howard Marshall, The Acts of the Apostles: An Introduction and Commentary (Grand Rapids: Eerdmans, 1980), 105
}

kai panta ta en autois) secara literal berarti Engkaulah yang telah membuat langit dan bumi dan laut dan segala sesuatu di dalamnya. Pernyataan tersebut merupakan bukti Allah yang penuh kemahakuasaan, Allah yang berdaulat, Allah yang berotoritas, Allah yang berkuasa, Allah yang mendengar dan menjawab doa, karena Ia yang telah menciptakan langit, bumi dan lautan serta isinya. Komunitas berdoa memohon supaya Allah yang sama menyatakan mujizat, Tuhan yang berkuasa, maka Tuhan dapat melakukan mujizat. Jawaban atas doa-doa umat-Nya adalah kedaulatanNya, sekalipun umat-Nya tidak menerima apa yang didoakan, umatNya tetap berdoa kepada-Nya. Tentunya Tuhan akan melakukan untuk orang-orang kudus-Nya, untuk mencapai tujuan-Nya untuk memenuhi janji-janji-Nya dan untuk kebaikan umat-Nya serta untuk menyatakan kemuliaan nama-Nya.

Jadi mengakui kedaulatan Allah dalam berdoa adalah cara yang sangat efektif dan sangat bemanfaat untuk mengawali doa baik berdoa secara pribadi maupun kelompok (bersamasama). Karena ketika umat-Nya 
mengakui kedaulatan Allah dalam berdoa akan terjadi beberapa hal, yaitu umat-Nya akan merendahkan diri di hadapan Allah, umat-Nya akan menerimakehendak dan rencana Allah dalan hidup umat-Nya, dan umat-Nya akan memuji Allah apapun yang dialaminya. Orang-orang percaya yang mengalami tekanan dan kesulitan hidup merupakan kesempatan untuk berdoa kepada Allah sebagai Bapa dan Tuhan yang memegang kendali, pada saat umatNya berdoa juga merupakan kesempatan untuk mengakui kedaulatan-Nya dalam situasi sesulit apapun. Setiap orang percaya berdoa dengan mulai mengakui kedaulatan Allah, dan jika tidak mengakui atau menyakini kedaulatan Allah, iman dan kehidupan rohaninya akan kehilangan substansinya.

\section{Indahnya Doa: Rencana Allah}

Babak berikutnya dalam Kisah Para Rasul 4:25-28 dapat ditemukan sebuah pernyataan mengenai berdoa sesuai dengan rencana Allah melalui inspirasi dari Roh Kudus dengan perantaraan raja Daud. Menurut, Kistemaker mencatat bahwa "kehidupan pada awal kekristenan memiliki kecenderungan yangmengacu pada kehidupan Daud dengan mengutip dari Kitab Mazmur." ${ }^{24}$ Kitab Mazmur dan kisah hidup Daud, dalam Perjanjian Lama dinyatakan bahwa hati Daud yang sangat dekat dengan Tuhan dan hidupnya berkenan kepada-Nya. Demikian juga kehidupan gereja mula-mula, sebab hanya kitab Perjanjian Lama (LXX) adalah Kitab Suci yang mereka miliki saat itu. Juga tidak heran, jika banyak dari orangorang Kristen awal adalah mantan penganut Yahudi yang yakin bahwa Yesus adalah Mesias yang dijanjikan. Para rasul berkhotbah dan berdoa seperti di dalam Kisah Para Rasul 3-4 merupakan bukti bagaimana Injil diberitakan kepada komunitas Yahudi. Doa-doa dalam Alkitab khususnya dalam Kisah Para Rasul mengajarkan kita bagaimana berdoa pada masa sekarang ini.

Pernyataan "dan oleh Roh Kudus dengan perantaraan hamba-Mu Daud"

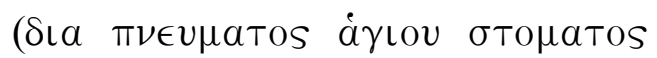

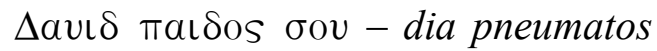
hagiou stomatos Dauid paidos sou) secara literal melalui Roh Kudus dengan mulut Daud hamba-Mu. Ayat ini merupakan kutipan dari Mazmur

\footnotetext{
${ }^{24}$ Simon J. Kistemaker, Acts (NTC: Grand Rapids: Baker Academic, 1990), 166
} 
2:1-3 (yang dikutip dari Septuaginta), ini menyatakan bahwa peristiwaperistiwa yang dialami oleh orangorang percaya telah dinubuatkan oleh para penulis Perjanjian Lama. Ini membuktikan bahwa Mazmur mengacu pada nubuatan Mesias. Dengan demikian, hal itu jelas-jelas dipahami oleh orang-orang Yahudi. Dalam Mazmur 2 merupakan gambaran bahwa bangsa-bangsa melawan Tuhan dan Mesias.

Ini adalah deklarasi para rasul, yang dipakai dalam doa yang khusyuk, bahwa Allah sendiri telah berbicara melalui Roh Kudus dengan perantaraan mulut Daud. Pernyataan ini adalah bagian isi kedua dari doa mereka, indahnya berdoa dalam persekutuan Kristen. Pada bagian pertama, mereka mengakui kekuasaan atau kedaulatan Allah untuk memerintah, bertindak dan menjawab doa umat-Nya. Doa mereka mengutip nubuatan dalam Mazmur Daud, peristiwa yang dialami oleh para rasul juga telah dinubuatkan. Sekalipun telah diramalkan mereka berdoa naik banding kepada Allah, supaya Allah melindungi mereka. Nubuatan tentang datangnya masa kesulitan dan perlawanan yang menghalang-halangi pemberitaan Injil, sudah datang waktunya.

Berdasarkan ayat 25b-27 menunjukkan beberapa kelompok yang melawan Yesus yang diurapi. Kelompok-kelompok itu antara lain:

Pertama; bangsa-bangsa. Kata

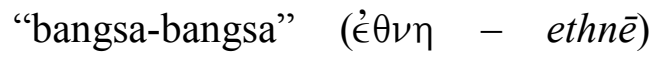
berasal dari kata ejqno (ethnos) yang biasanya menunjuk bangsa-bangsa kafir, atau bangsa-bangsa bukan Yahudi. Bangsa-bangsa non Yahudi ini yang akan menjadi sasaran pmberitaan Injil. Bangsa-bangsa ini menjadi rusuh $(\mathrm{TL}=$ huru-hara; BIS $=$ marah; Drewes ${ }^{25}$ menerjemahkan $=$

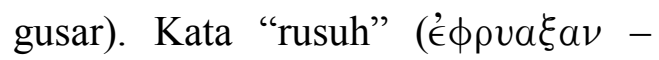
ephruaksan) berbentuk aorist active indicative dari kata $\phi \rho v a \sigma \sigma \omega$ (phruassō) yang berarti berdengus karena marah. Kata ini hanya ada di sini saja dalam Perjanjian Baru. Kata ini dapat diungkapkan dalam bentuk kiasan "terbakar hati mereka" atau "wajah mereka menjadi merah membara." Bangsa-bangsa kafir melawan Mesias dengan marah yang dalam.

Kedua; suku-suku bangsa. Kata "suku-suku bangsa" sebenarnya sama dengan bangsa-bangsa di atasnya,

${ }^{25}$ B. F. Drewes, Kisah ParaRasul, (Jakarta: BPK Gunung Mulia, 2014), 91. 
tetapi kata yang dipakai adalah kata laoi lebih tepat diterjemahkan bangsa-bangsa lain (masyarakat), kemungkinan bangsa Yahudi tercakup di dalamnya. Sedangkan ungkapan "mereka-reka perkara yang sia-sia" $\quad(€ \mu \in \in \lambda \in T \eta \sigma \alpha \nu \quad \kappa \in \nu \alpha-$ emeletēsan kena) berbentuk aorist active indicative dari kata $\mu \in \lambda \in T a \omega$ (meletaō) yang berarti memperhatikan, mereka-reka, melakukan. Kata ini hanya muncul di dalam ayat ini dan dalam 1 Timotius 4: 15 yang diterjemahkan "perhatikanlah." Kata "sia-sia" yang digunakan di sini kena (kena) yang berasal dari kata $\kappa \in \nu$ OS (kenos) yang berarti kosong, hampa, sia-sia, bodoh. Di sini berarti bahwa mereka menyusun rencana yang ternyata menjadi sia-sia atau tidak efektif, kosong dan hampa. Mereka berusaha untuk melawan Mesias, perbuatan itu menjadi sia-sia. Mereka berencana melakukan sesuatu yang tidak mampu mereka lakukan, yaitu menentang Tuhan. Usaha mereka sia-sia karena mereka tidak cukup kuat untuk melawan Allah.

Ketiga; raja-raja dunia. Pernyataan "raja-raja dunia bersiap-

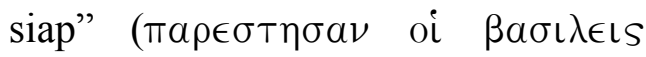

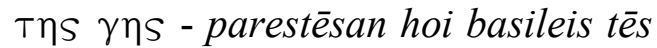
$g \bar{e} s)$ secara literal berarti raja-raja di bumi telah datang. Kata "siap-siap"

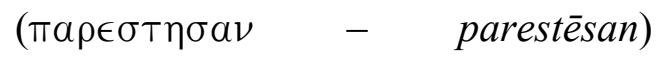
berbentuk aorist active indicative dari

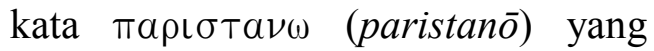
berarti menempatkan di samping, menyuruh berdiri di samping, sudah tiba, datang, menyiapkan diri untuk bertempur. Yang dimaksud raja-raja dunia bukan berarti raja-raja yang menguasai dunia ini atau memerintah seluruh dunia ini, tetapi istilah dunia

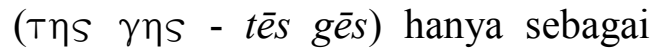
tempat mereka menjadi raja atau rajaraja yang memerintah Negara-negara yang ada di dunia. Ayat ini merupakan kutipan Mazmur 2:1-3 yang mana pemazmur telah menetapkan lebih khusus raja dan penguasa yang akan menentang Mesias. Para penguasa itu telah nyata menjadi lawan bangsa Yahudi. Dan kelak akan lebih banyak lagi para penguasa yang menentang penyebaran Injil kepada bangsabangsa. Gereja mula-mula mempunyai anggapan bahwa musuhmusuh di dalam Mazmur 2 diidentifikasikan dengam kelompok orang atau pribadi yang menentang Yesus seperti bangsa Yahudi, bangsa 
Romawi, Herodes, Kaisar atau Pilatus.

Keempat; para pembesar. Kata

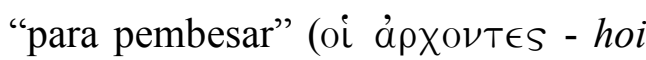
archontes) secara literal berarti para penguasa, atau anggota Sanhedrin. Yang dimaksud di sini adalah para imam kepala yang merupakan anggota yang terkemuka dalam Sanhedrin atau Mahkamah Agama Yahudi. Pemimpin-pemimpin ini mempunyai kekuasaan dalam bidang politik

Kelima; Herodes. Yang dimaksud dengan Herodes di sini adalah raja yang dikenal sebagai Agripa (bdk. Kis. 21:1). Ia adalah anak dari Aristobulus dan cucu dari Herodes Agung. Setelah ayahnya menjalani hukuman mati pada tahun 7 sM, ia dibesarkan di Roma, erat berhubungan dengan keluarga kaisar. Pada tahun $23 \mathrm{M}$ ia mempunyai hutang, sedemikian besarnya sehingga ia harus meninggalkan Roma. Untuk suatu kurun waktu tertentu ia menerima perlindungan di Tiberias dari pamannya, Antipas, berkat bantuan kakaknya yang perempuan, Herodias, yang baru saja dinikahi Antipas. Herodes yang melawan Yesus juga menjadi pokok doa para rasul.

Keenam; Pontius Pilatus. Kemungkinan yang disebut dengan Pontius Pilatus di sini adalah orang Romawi, dari golongan penunggang kuda, atau kelas menengah bagian atas. Nama depannya tidak dikenal, tetapi nama Pontius memberi kesan bahwa ia keturunan Samnit, sedangkan nama keluarganya, Pilatus, nampaknya mengacu bahwa leluhurnya militer. Sedangkan Filo tidak berkata sesuatu yang baik tentang Pilatus. Dalam De Legatione ad Gaium 301 ia menggambarkan Pilatus bertabiat kasar dan keras kepala, dan berwatak pendendam dan pemarah. Ia menceritakan tentang suap, tindakan didorong oleh kedengkian, pembunuhan keji tanpa pengadilan, kekurangajaran beruntun dan paling menyakitkan hati sehingga orang Yahudi mengutukinya. ${ }^{26}$

Umat Allah dalam Kisah Para Rasul melihat apa yang mereka alami sebagai bagian rencana Allah yang telah dinubuatkan dalam Perjanjian Lama. Maka di dalam doa mereka

\footnotetext{
${ }^{26}$ D. H. Weaton, "Pilatus" dalam J. D. Douglas, Ensiklopedi Alkitab Masa Kini (Jakarta: Yayasan Komunikasi Bina Kasih/OMF), 1995, II:266-267
} 
menyebutkan bahwa orang-orang yang berniat jahat telah berkumpul untuk menentang kebenaran yang dari Allah dan Yesus yang telah diurapi. Apa yang mereka alami merupakan bagian dari rencana Allah karena itulah mereka kerjakan untuk memberi luluasa kuasa dan rencana Allah menjadi nyata. Kelompokkelompok jahat bersekongkol menentang dan melawan Yesus karena Allah mengijinkan. Semua ini adalah bagian dari rencana Allah.

Paulus telah menyatakan dalam Roma 8: 28; "Kita tahu sekarang, bahwa Allah turut bekerja dalam segala sesuatu untuk mendatangkan kebaikan bagi mereka yang mengasihi Dia, yaitu bagi mereka yang terpanggil sesuai dengan rencana Allah.” Sekalipun kita sebagai umat-Nya tidak melihat rencana-Nya, namun Allah memunyai rencana yang baik bagi umat-Nya. Demikian Yeremia menyatakan; "Sebab Aku ini mengetahui rancangan-rancangan apa yang ada pada-Ku mengenai kamu, demikianlah firman TUHAN, yaitu rancangan damai sejahtera dan bukan rancangan kecelakaan, untuk memberikan kepadamu hari depan yang penuh harapan" (Yer. 29:11). Seringkali umat-Nya bertanya mengapa Allah mengerjakan atau membiarkan berbagai kejadian terjadi padanya dan situasi-siatuasi tertentu menimpa umat-Nya. Namun ketika umat-Nya mengakui bahwa tangan Tuhanaktif berkerja, iman kita akan dikuatkan dan sukacita akan ditambah-tambahkan.

Jika umat-Nya mengakui di dalam imannya bahwa Allah memiliki rencana dalam segala sesuatu terjadi terhadap hidup kita, semua itu akan membuat indah hidup kita. Hanya Roh Kuduslah yang dapat menganugerahkan sukacita dan keindahan dalam hidup kita. Doa yang demikian adalah kepuasan di tengah-tengah kesulitan. Brake menyatakan bahwa sukacita dalam kesulitan bukan berarti kita menikmati penderitaan dan cobaan dengan sadis, tetapi kita tahu bahwa Allah memiliki rencana dalam segala penderitaan tersebut dan kita bias terus bersukacita karena mengetahui Allah berencana untuk kita. ${ }^{27}$

\footnotetext{
${ }^{27}$ Brake, Op.cit., 91.
} 


\section{Isi Doa: Keberanian \\ Memberitakan Injil}

Bagian ketiga dari doa yang penuh dengan kuasa adalah isi atau materi doa jelas, supaya doa menjadi efektif. Yang dimaksud dengan isi doa di sini adalah pokok doa yang berkaitan dengan keadaan yang dihadapi khususnya melaksanakan kehendak Tuhan yaitu untuk memberitakan injil dengan berani. Dalam ayat 29-30; "Dan sekarang, ya Tuhan, lihatlah bagaimana mereka mengancam kami dan berikanlah kepada hamba-hamba-Mu keberanian untuk memberitakan firman-Mu. Ulurkanlah tangan-Mu untuk menyembuhkan orang, dan adakanlah tanda-tanda dan mujizat-mujizat oleh nama Yesus, Hamba-Mu yang kudus." isi doa mereka antara lain:

Pertama;lihatlah bagaimana kelompok-kelompok jahat mengamcam.Ungkapan "bagaimana mereka mengancam kami” ('́Tı Tás

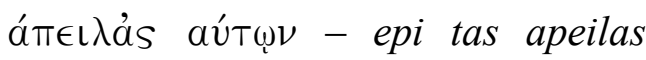
auton) secara literal berarti pada ancaman-ancaman mereka. Ancamanancaman mereka adalah tidak mengijinkan memberitakan Injil. Para rasul tidak mendapat kebebasan untuk memberitakan Injil. Komunitas
Kristen menyadari adanya ancamanancaman dari para anggota Mahkamah agama bangsa Yahudi, yang kemungkinan akan menganiaya atau membunuh para rasul yang memberitakan Injil. Ungkapan "lihatlah bagaimana mereka mengancam kami" bukan berarti mereka meminta supaya Allah menghilangkan penganiayaan, akan tetapi memohon supaya Allah memberikan kepada mereka keberanian untuk memberitakan Injil. Para rasul tidak meminta agar Allah menurunkan api dan belerang dari langit untuk menghancurkan musuhmusuh mereka (Luk. 9:51-56), melainkan mereka meminta kuasa dari Allah untuk memberitakan Injil dengan menyatakan peyembuhan orang sakit dan menyatakan tandatanda dan mujizat-mujizat (Mat. 5:10$12,43-48)$.

Kedua;berikanlah ... keberanian untuk memberitakan Injil. Kata

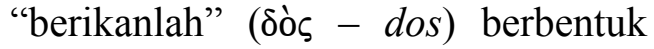
aorist active imperative dari kata

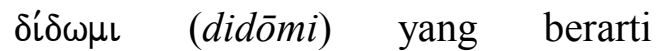
memberikan, mengijinkan, mempercayakan. Ungkapan ini lebih merupakan sebuah permohnan doa minta untuk dapat melakukan 
sesuatu, bukan sekedar meminta ijin. Permintaan para anggota komunitas Kristen supaya Allah memberikan keberanian untuk memberitakan Injil. Ungkapan "keberanian untuk memberitakan firman-Mu" $\quad(\mu \in \tau \grave{\alpha}$

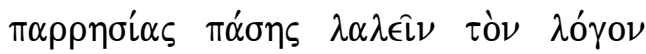
бou - meta parrēsias pasēs lalein ton logon sou) secara literal berarti dengan segala keberanian mengatakan firman-Mu.Mungkin anggapan para rasul penganiayaan yang mereka alami bukan sebagai penghambat dalam pemberitaan Injil, tetapi yang menghambat pemberitaan Injil adalah ketakutan dan ketidakberanian.

Ketiga; ulurkanlah tangan-Mu untuk menyembuhkan orang sakit. Ungkapan "ulurkanlah tangan-Mu"

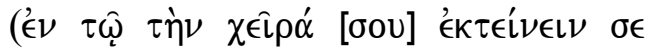

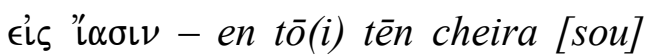
ekteinein se eis iasain) secara literal berarti dengan tangan-Mu yang berkuasa Engkau mengulurkan. Kata

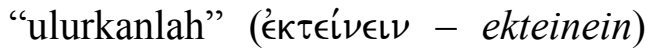
berbentuk present active infinitive yang berasal dari kataék $\tau \in \dot{l} \nu \omega$ (ekteinō) berarti mengulurkan, melabuhkan (sauh). Teks Yunani ayat ini masih merupakan bagian dari ayat 29. Ungkapan ini masih berkaitan dengan permohonan doa di dalam ayat 29, yaitu "lihatlah bagaimana mereka mengancam kami" dan "berikanlah keberanian untuk memberitakan firman-Mu." Ungkapan ini merupakan gaya bahasa antropomorfisme, yaitu menyatakan Allah dapat tangan-Nya yang berkuasa, biarkanlah orang-orang melihat bahwa Engkau sungguhsunggu berkuasa untuk mengadakan penyembuhan orang yang sakit dan tanda-tanda serta mujizat-mujizat

Keempat; adakanlah tanda-tanda dan mujizat-mujizat.Pernyataan "dan adakanlah tanda-tanda dan mujizat-

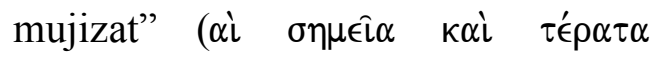

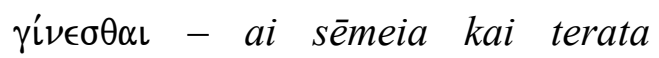
ginesthai) secara literal berarti dan tanda-tanda ajaib dan keajaiban-

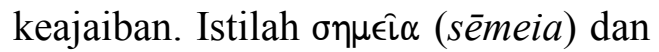
kata $\tau$ '́́p $\alpha \alpha$ (terata) sebenarany kedua istilah yang tidak berbeda maknanya. Kedua istilah ini kemungkinan dipakai bersama-sama untuk menegaskan atau saling melengkapi (penjelasan dapat dilihat dalam Kis. 2: 19, 43).Kata sēmeion berarti distinguishing mark, sign; miracle. ${ }^{28} \mathrm{Di}$ dalam Septuaginta

\footnotetext{
${ }^{28}$ Horst Balz and Gerhard Schneinder (ed), Exegetical Dictionary Of The New
} 
(LXX) kata sēmeion hampir selalu ditransliterasikan dari bahasa Ibrani 'et (Aram 'at-bdk. Kel. 7: 3; Ul. 4: 32; 6: 22). Sedangkan dalam Injilinjil dan Kisah Para Rasul kata sēmeion yang berarti tanda; tanda (peringatan); tanda (ajaib); tanda (heran); tanda (hebat); tanda (yang mengerikan). ${ }^{29}$

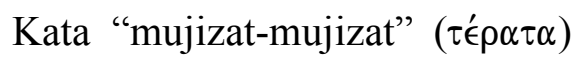
yang berarsal dari kata tera (teras) yang berarti miracle, wonder, miraculous, sign, portent. ${ }^{30}$ Dalam Septuagenta kata tera diterjemahkan dari bahasa Ibrani mopet (bdk Kel. 7: 3 otot umpetim). Susanto mengartikan kata $t \in \rho a s$ adalah keajaiban; mijizat. ${ }^{31}$ Selain istilah-istilah yang ada di atas Richardson menambahkan bahwa tanda-tanda dan mujizatmujizat di dalamnya adalah kuasa kata yang digunakan, energi $(\epsilon \in \mathcal{\epsilon} \rho \gamma\llcorner\alpha=$ energeia $)$ yang berarti kekuatan, kuasa yang hebat $(\beta \iota \alpha=$ bia), kekuatan secara khusus fisik $(\mathfrak{i} \times \cup \mathrm{S}=$ ischus $)$, kekuatan kuasa yang dinyatakan $(\kappa \rho а \tau о \mathrm{~S}=$ kratos $)$ dan otoritas, kebebasan bertindak yang dinyatakan.

Testament, 3 jilid (Grand Rapids: Wm B. Eerdmans Publishing Co, 1994) III : 238

${ }^{29}$ Susanto, Op.cit., II: 704.

${ }^{30} \mathrm{Balz}$ and Zchneider, Op. Cit, III: 350

${ }^{31}$ Susanto, Op. Cit,. 704
Dalam Perjanjian Baru istilahistilah tersebut di atas biasanya dihubungkan dengan penyembuhan, pengusiran setan, pembebasan dan sebagainya atau tanda-tanda dan mujizat-mujizat lebih khusus dihubungkan dengan pekerjaan Roh Kudus dan karunia-karunia Roh Kudus. Jadi yang dimaksud dengan tanda-tanda dan mujizat-mujizat adalah suatu peristiwa yang terjadi adanya manifestasi Allah oleh Roh Kudus yang melalui Allah sendiri, para rasul-Nya maupun gereja-Nya.

Masa kini kita harus mendoakan agar para pemberita Injil, misionaris dan orang-orang percaya dengan berani untuk memberitakan Injil. Seperti Paulus meminta jemaat di Efesus supaya mendoakannya untuk berani membuka mulut menyatakan rahasia Injil. "juga untuk aku, supaya kepadaku, jika aku membuka mulutku, dikaruniakan perkataan yang benar, agar dengan keberanian aku memberitakan rahasia Injil" (Ef. 6: 19). Demikian juga Epafras bergumul derdoa untuk jemaat Kolose. "Salam dari Epafras kepada kamu; ia seorang dari antaramu, hamba Kristus Yesus, yang selalu bergumul dalam doanya untuk kamu, 
supaya kamu berdiri teguh, sebagai orang-orang yang dewasa dan yang berkeyakinan penuh dengan segala hal yang dikehendaki Allah" (Kol. 4: 12). Dan Paulus juga meminta agar jemaat Kolose untuk mendoakan supaya berani memberitakan Injil. "Berdoa jugalah untuk kami, supaya Allah membuka pintu untuk pemberitaan kami, sehingga kami dapat berbicara tentang rahasia Kristus, yang karenanya aku dipenjarakan. Dengan demikian aku dapat menyatakannya, sebagaimana seharusnya" (Kol. 4:3-4). Sebaliknya sekarang ini, kita sering mendengar orang-orang Kristen berdoa meminta keselamatan, memohon kelepasan, meminta kenyamanan, meminta keadaan yang baik, meminta berkatberkat jasmani. Mereka melakukannya dengan melupakan bagian yang penting, yaitu meminta keberanian untuk memberitakan Injil.

\section{Dampak Doa}

Bagian yang keempat dari doa yang penuh kuasa adalah dampak yang luar biasa dari doa yang dilakukan dengan tekun.Pernyataan "dan ketika mereka sedang berdoa"

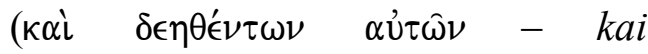
deèthentōn autōn) secara literal berarti lalu setelah mereka berdoa. Kata $\delta \epsilon \eta \theta^{\prime} \in \tau \tau \omega \nu \quad$ (deēthentōn) berbentuk aorist passive participle

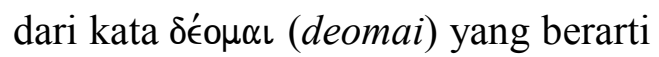
meminta, berdoa. Dalam teks Yunani menunjukkan bahwa setelah mereka berdoa baru terjadi goyangan. Goyangan pada tempat mereka bukan pada saat berdoa, tetapi setelah berdoa.Sedangkan ungkapan "goyanglah tempat mereka

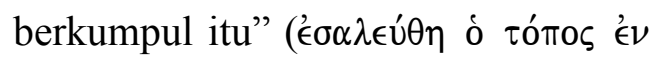

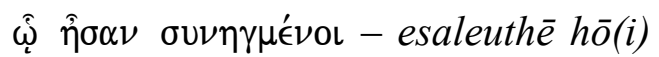
topos en ho(i) èsan sunēngmenoi) secara literal berarti tempat dimana mereka berkumpul digoyang. Kata

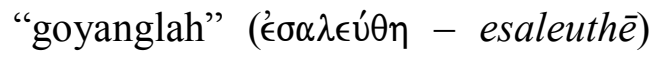
berbentuk aoris passive indicative dari kata $\sigma \alpha \lambda \in \cup ́ \omega$ (saleuō) yang berarti menggoyangkan, menggoncangkan, menghasut. Terjemahan yang lebih tepat digoyangkan (pasif), digoyangkan tempat mereka berkumpul di sini menunjukkan bahwa Allah itu menjawab doa mereka. Kemungkinan goyangannya itu merupakan bukti Roh Kudus turun menjamah mereka, dengan tujuan Roh Kudus tersebut memberikan keberanian untuk memberitakan Injil. 
Dampak berikutnya adalah "dan mereka semua penuh dengan Roh

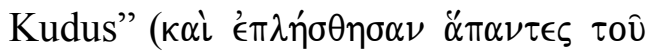
¿́yíov $\pi \nu \in \dot{\mu} \mu \alpha \tau o \varsigma$ - kai eplēsthesan hapantes tou hagiou pneumatos) secara literal berarti mereka semua dipenuhi oleh Roh Kudus. Kata

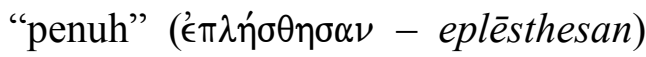
berbentuk aorist passive indicative berasal dari kata $\pi i \mu \pi \lambda \eta \mu \iota$ (pimplēmi) yang berarti memenuhi (lih. Kis. 2:4; $3: 10 ; 4: 8,31 ; 5: 17 ; 9: 17 ; 13: 9 ; 19$ : 29). Artinya Roh Kudus yang berasal dari Allah hadir memenuhi mereka, Roh Kudus menguasai mereka. Istilah ini merupakan kesukaan Lukas untuk menyatakan bahwa Alla memberikan Roh Kudus yang dijanjikan itu untuk memampukan orang-orang percaya untuk melakukan tugas khusus. Di sini Roh Kudus diberikan untuk menguasai para rasul untuk memberitakan firman Allah dengan berani. Jadi peristiwa kepenuhan Roh Kudus di sini adalah untuk tugas khusus yaitu keberanian untuk memberitakan Injil. Perhatikan juga bahwa bahasa lidah tidak disebutkan dalam fenomena ini. Lukas menyebutkan bahasa Roh di dalam Kisah Para Rasul ketika dikaitkan dengan konteks pekabaran Injil lintas budaya atau etnis atau karena hambatan geografis.

Dan dampak yang doa yang dahsyat adalah "lalu mereka memberitakan firman Allah dengan

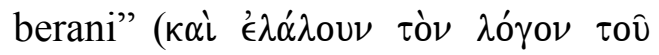

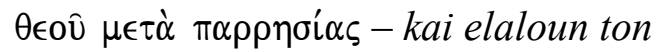
logon tou theou meta parrēsias) secara hurufiah berarti lalu merekan mengatakan firman Allah dengan berani. Kata "memberitakan" $\left({ }^{\prime} \lambda \alpha^{\prime} \lambda\right.$ ouv - elaloun $)$ berbentuk imperfect active indicative dari kata $\lambda \alpha \lambda \epsilon^{\prime} \omega$ (laleō) yang berarti berbicara, mengatakan. Maksudnya adalah mereka mulai berbicara, mulai mengatakan firman Allah. Istilah mulai berbicara di sini merupakan suatu istilah untuk melakukan kegiatan pemberitaan Injil atau pengajaran Kristen. Sedangkan kata

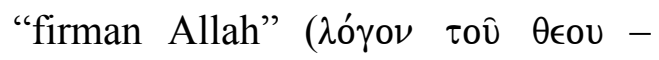
logon tou theou) mempunyai persamaan dengan firman Allah dalam ayat 29, yang berarti kemungkinan menunjuk pada pengertian yang khusus yaitu berita dari Allah, pesan yang berasal dari Allah.

Jadi jawaban Allah atas doa komunitas Kristen mula-mula, yang mana Allah dengan menggoyangkan 
tempat mereka berdoa sebagai tanda kehadiran Allah (Luk. 21:26; Kis. 16:26; Ibr. 12:26-27; Mzm. 114:7; Yes. 6:4; Yeh. 38:19; Yoel 3:16; Am. 9:5; Hag. 2:7), dan mereka dipenuh (pasif) dengan Roh Kudus. Kepenuhan Roh Kudus atas mereka merupakan kuasa yang memberikan keberanian mereka untuk memberitakan Injil, walaupun mendapat perlawanan dari orangorang yang tidak senang dengan perkembangan Injil. Peristiwa ini bukan baptisan Roh Kudus ulang, akan tetapi Roh Kudus memenuhi kembali guna memperlengkapi para rasul untuk melayani.

Seharusnya kita sebagai orangorang percaya bertekun berdoa kepada Allah yang mempunyai kedaulatan, karena Allah mempunyai rencana, Allah mempunyai kehendak yang baik, Allah ingin mengerjakan perkara-perkara besar. Allah kita adalah yang masih bekerja dan berkarya dalam dan melalui gerejaNya atau umat-Nya.

\section{PENUTUP}

Ketika orang-orang percaya dalam Kisah Para Rasul sedang mengalami ancaman penganiayaan, mereka bersatu berdoa dengan tekun. Allah mendengar dan mengabulkan doa mereka. Mereka berdoa dengan mengandalkan kedaulatan Allah, mengakui segala yang terjadi adalah rencana Allah, mereka berdoa dengan jelas isi doanya serta berdoa dalam kuasa Roh Kudus, maka Allah menjawab doa mereka.Jika Allah pada saat itu bisa melakukan hal itu, sekarangpun Allah yang sama dapat melakukannya bagi umat-Nya.Gereja masa kita juga harus berdoa seperti gereja mula-mula, karena Allah memanggil gereja-Nya untuk menjadi pendoa-pendoa yang tekun, khususnya berdoa supaya gereja (umat-Nya) mempunyai keberaian untuk memberitakan Injil kepada segala bangsa. Berdoalahkepada Allah dengan sikap yang sama seperti yang ada pada gereja mula-mula.Ada seseorang mengatakan: Sorrow looks back, worry looks around, faith looks up (kesedihan melihat kebelakang, kekuatiran melihat ke sekeliling, iman melihat ke atas). Mari kita berdoa! 


\section{DAFTAR PUSTAKA}

Balz, Horst and Schneinder, Gerhard (ed).Exegetical Dictionary Of The New Testament, 3 vol. (Grand Rapids: Wm B. Eerdmans Publishing Co, 1994.

Barrett, C. K.The Acts of the Apostles The International Critical Commentary. Edinburgh: T \& T Clark, 1994.

Brake, Andrew. Menjalankan Misi Bersama Yesus Bandung: Kalam Hidup, 2016

Bruce, F. F. The Acts of the Apostles: The Greek Text with Introduction and Commentary. Grand Rapids, MI: Eerdmans, 1975.

Drewes, B. F., Kisah Para RasulJakarta: BPK Gunung Mulia, 2014.

Fitzmyer, Joseph A.The Acts of the Apostles Anchor BibleNew York: Doubleday, 1998.

Kistemaker, Simon J. Acts Grand Rapids: Baker Academic, 1990.

Ladd, George Eldon. A Theology of the New Testament Grand Rapids: Eerdmans, 1974
Marshall, I. Howard.The Acts of the Apostles: An Introduction and Commentary Grand Rapids: Eerdmans, 1980. . Luke: Historian and Theologian Grand Rapids, Michigan: Zondervan, 1970.

Morris, Leon.New Testament Theology,Malang: Gandum Mas, 1999.

Newman, Barclay M. dan Nida, Eugene A.Pedoman Pebafsiran Alkitab Kisah Para Rasul Jakarta: Yayasan Karunia Bakti Budaya Indonesia, 2006.

Susanto, Hasan.Perjanjian Baru Interlinear Yunani Indonesia Konkordansi Perjanjian Baru, 2 jilidJakarta: Lembaga Alkitab Indonesia, 2003.

Weaton, D. H. "Pilatus" dalam J. D. Douglas,Ensiklopedi Alkitab Masa KiniJakarta: Yayasan Komunikasi Bina Kasih/OMF), 1995, II:266267 